\title{
Anne Fastrup
}

\section{Cultural Liminality in Don Quixote}

\begin{abstract}
English Summary
Miguel de Cervantes' two-volume satire from 1605 and 1615, Don Quixote de la Mancha, has often been been proclaimed the first European novel, especially by the continental theory of the novel. Most renowned in that regard is Milan Kundera's description in The Art of the Novel of Don Quixote as the first narration in the literary history of Europe testifying to the absence of God. Thus for Kundera, Cervantes' master piece demonstrates the close relationship between the genre of the novel, on the hand, and the rise of a scepticist, secular and worldlyminded mentality characteristic of the European Enlightenment, on the other hand. Being influenced by the general »re-historizing « of the literary studies that we are facing in these years, more recent Cervantine research has taken up topics that played a central role in the the cultural history of Golden Age Spain. Consequently, we have been witnessing a lot of studies focused on the representation of gender, ethnicity, identity politics etc. Within the frame of the cultural history approach to Don Quixote we also see examples of new biographical readings basing the literary analysis on a thorough historical reconstruction of Cervantes' life and times, in particular with regard to his involvement in the war against the Turks. In my article »Cultural Liminality in Don Quixote. Cervantes and the Algerian experience ", I approach the question of Don Quixote as the first novel by combining the Bakhtinian theory of the novel with recent attempts at historical reconstruction.
\end{abstract}

\section{Anne Fastrup}

Lektor ved Afdeling for litteraturvidenskab, Københavns Universitet.

KふK 103 (2007), 80-107 


\section{Kulturel liminalitet i Don Quixote}

\section{Cervantes og den »algierske erfaring «}

Historiske faktorer som Europas sekularisering, individets frigørelse fra religiøse og standsmæssige bestemmelser og fremvæksten af et kommercielt bogmarkede har ofte dannet ramme omkring diskussionen af romangenrens opkomst. I forlængelse heraf er et relativt begrænset katalog af længere fiktive prosatekster - Don Quixote (1605/1615), La Princèsse de Clèves (1678), Robinson Crusoe (1719), Pamela (1741) - på skift blevet kåret som eksempler på romanens historiske gennembrud. De nationalt orienterede engelske romanhistorikere har med udgangspunkt i filosofiog realhistoriske faktorer som bl.a. erfaringsfilosofi, puritanisme, liberalisme og journalistikkens opkomst typisk udråbt det tidlige 1700-tals engelske romaner som de første af slagsen. I den kontinentale romanteori har der derimod været en klar tendens til at pege på Miguel de Cervantes to bindsværk Don Quixote som genrens fødsel. Mest kendt er nok Georg Lukács indflydelsesrige beskrivelse af værket som »modernitetens epopé« i Romanens teori (1920) og Milan Kunderas beslægtede karakteristik af Don Quixote i Romankunsten (1986) som det første eksempel på romangenrens konstitutive evne til at skildre den menneskelige livsverden efter Guds død. I den kontinentale romanteori har der med andre ord været tradition for at knytte romanens fødsel sammen med den sekularisering og affortryllelse af verden, som begynder i forbindelse med reformationen, empirismen og rationalismen sidst i det 16. og det 17. århundrede.

Bag de overordnede historiske forandringsprocesser, som romanens og således også Don Quixotes tilblivelse knyttes til, skjuler der sig imidlertid mere specifikke, lokale historiske omstæendigheder og forhold, som formentlig ofte har spillet en lige så stor rolle for de konkrete manifestationer af genren som de makrohistoriske forhold. Don Quixote er præget af og for så vidt også muliggjort af nogle specifikke spanske forhold, ikke mindst af landets etniske, religiøse og politiske spændinger samt af den bredere geopolitiske situation i 1600-tallets Middelhavsregion. Ambitionen i denne artikel er at undersøge, hvorledes disse spændinger og kon- 
flikter er blevet konfigureret og fortolket i Don Quixote på flere niveauer - det genealogiske, det fortælle- og genremæssige ${ }^{1}$ og det tematiske - og i tilknytning til denne analyse at diskutere en tese om romangenrens oprindelse, i hvilken den sproglige og kulturelle liminalitet i Spanien og Middelhavsregionen vil spille en fremtrædende rolle.

\section{Bevagelser henover gransen liminalitet}

Som land, som stat og nation var Cervantes' Spanien i lighed med andre spirende stater i Europa præget af kongemagtens forsøg på at samle undersåtterne i et kulturelt fællesskab. Dette fællesskabs funktion var naturligvis at frembringe lydighed og forpligtethed hos den enkelte undersåt over for den religiøse og politiske øvrighed. Den absolutistiske statsdannelsesproces forløb imidlertid anderledes i Spanien end i eksempelvis England og Frankrig, især fordi landet (eller store dele af det) havde været under muslimsk herredømme frem til 1492, og fordi det i det hele taget rummede en etnisk og religiøst sammensat befolkning. Af samme grund ledsages og understøttes etableringen af en spansk, absolutistisk stat i det 16. århundrede af en vedholdende diskriminationspolitik med dertil hørende etniske renhedsforestillinger.

Don Quixote indskriver sig i dette spændingsforhold mellem den etniske, religiøse og kulturelle renhedsbestræbelse, institutionaliseret i inkvisitionen og i »loven om det rene blod ", og den faktiske etnisk-kulturelle sammensathed i landet. Denne spænding mellem den illusoriske bestræbelse på at skabe en katolsk monokultur på den ene side og den brogede virkelighed på den anden side gestalter sig i romanen som en generel ambivalens med hensyn til personeres sande etniske identitet: »Er du kristen eller maurer«, spørges den mauriske kvinde Zoraida således om i »Krigsfangens beretning «, og spørgsmålet klinger med gennem hele romanen. Alle svarer: »Jeg er kristen «, men er det sandt? Eller er det en illusion, man foregøgler sig selv og sine omgivelser, fordi det er forbudt at være troende muslim eller troende jøde? Vi får sjældent noget svar, men overlades til en generel ambivalens med hensyn til personernes sande identitet.

Fokusering på menneskelig, sproglig og kulturel interaktion på tværs af kulturelle og sproglige grænser er en anden og lige så udbredt måde, hvorpå Cervantes intervenerer i tidens religiøse renhedspolitik. Denne interaktion kan sammenfattes i begrebet »liminalitet « for at understrege den geografiske, kulturelle og sproglige granses centrale betydning i dette temas udfoldelse i Don Quixote. ${ }^{2}$ Imidlertid er det ikke grænsen i sig selv, men derimod bevagelserne henover den og det rum, der åbner sig 
mellem kulturerne, der påkalder sig interesse og skildres. Der berettes i Don Quixote om personer, som krydser grænsen mellem den muslimske og den kristne verden, arabiske ord dukker op i det kastilianske sprog, som romanen ellers er skrevet på, der hentydes til hvordan "fremmede « sæder, skikke, mentalitet, moral og tro assimileres i eller erstatter den »medfødte « kultur - hvad end denne nu er maurisk eller spansk.

Romanhistorikeren og romanteoretikeren Mikhael Bakhtin har formuleret en tese om romangenrens oprindelse, hvori han netop argumenterer for, at sådanne intersproglige og interkulturelle bevægelser har spillet en vigtig rolle i forhold til litteraturens »romangørelse«. Don Quixote har spor efter, viser og undersøger sådanne »tværkulturelle « og »grænsekrydsende « bevægelser mellem den arabisk-muslimske og kastiliansk-katolske kultur. Rejsen henover denne grænse spiller en aktiv rolle på fortællerplanet samt i bogens interne genreovervejelser, og sidst, men ikke mindst tematiseres overskridelsen af grænsen i romanens fremstilling af den omgivende sociale, kulturelle og politiske verden. ${ }^{3}$ Lad os i første omgang iagttage Mikhael Bakhtins beskrivelse af litteraturens romangørelse i det tosprogede antikke Rom.

\section{Bakbtin - roman og flersprogethed}

I de to essays »From the Prehistory of Novelistic Discourse « og »Epic and the Novel « argumenterer Bakhtin for en sammenhæn mellem flersprogethed og de litterære genrers romangørelse. At sproglig og dermed også kulturel liminalitet ifølge Bakhtin udgør en væsentlig baggrund for litteraturens romangørelse siges faktisk helt eksplicit: »I sit inderste væsen udviklede denne diskurs [romanen] sig på grænselinjen mellem kulturer og sprog. $\ll^{4}$ Konkret henviser Bakhtin til den romerske satire og parodiske litteratur i det hele taget, nogle af de såkaldte forformer til romanen. Disse præ-romanagtige genrer var et resultat af de romerske digteres imitation, bearbejdning og udvikling af den hellenistiske litteratur og det græske sprog. Det klassiske Rom var som bekendt to-sproget. Latin var en slags »nationalt « folkesprog, mens græsk skønt et fremmed sprog taltes i senatet og fungerede som litterært sprog. Med Rom som historisk eksempel fremsætter Bakhtin nu følgende generelle udsagn om romanens oprindelse:

"... dens [romanens] opkomst skyldes et bestemt opbrud i den europriske civilisation $[\ldots]$ som skete, da socialt isolerede og kulturelt døve halv-patriarkalske samfund [blev erstattet] af en mangfoldighed af sprog, kulturer og tider [...] dette blev en afgørende faktor i 
romanens liv og tænkning. « ${ }^{5}$

Jo mere sproglig og kulturel påvirkning udefra, jo mere »interanimation « mellem kulturer og sprog, desto mere blomstrende vil den parodiske og selvrefleksive litteratur være. Ciceros retorik, Juvenals satire og Vergils reflekterede gendigtning af Illiaden, for blot at nævne nogle fă eksempler på den romanagtige romerske litteratur, var utænkelige uden den interanimation, som fandt sted i det antikke Rom. Det græske sprogs tilstedeværelse midt i det romerske politiske og litterære miljø betød, at en ny måde at arbejde kreativt med sproget på udvikledes. Digteren begyndte at se på sproget (latin såvel som græsk) udefra, med en andens blik:

»... den latinske digtning så sig selv i lyset af græsk, gennem det greske sprogs øjne; det var lige fra begyndelse en digtning med et sidelæns blik, en stiliseret digtning, der så at sige hegnede sig selv inde i sine egne fromt stiliserede citationstegn. $\ll^{6}$

De romerske digtere udviklede »et sidelæns blik « eller et skævt sideblik på deres eget sprog, idet de så på det gennem det græske sprog. Derved forlentes latin med en kreativ fremmedhed for digterne, som om dette sprog og dermed de litterære former, hvori det (også) manifesterede sig, var udhævet i citationstegn. Denne fremmedhed, denne distance eller dette refleksive perspektiv på sproget og stilen betød, at de romerske digtere kunne forskyde sig i forhold til deres egen kultur og dennes værdier, - en forskydning, der konkret gav sig udslag i den hyppige tilstedeværelse af ironi og flertydighed i den romerske litteratur.

Ingen tvivl om at Bakhtin havde til hensigt at sige noget principielt om romanens sproglige (og historiske) mulighedsbetingelser. Sammenhængen mellem flersprogethed og en romanagtig litteratur er ikke begrænset til kun at gxlde for digterne i det antikke Rom. Derfor giver det mening at transponere Bakhtins teori til det 16. århundredes Spanien og til Cervantes hovedværk Don Quixote, hvorved jeg imidlertid også betoner, hvad Bakhtin lader være underforstået, nemlig at denne interanimation mellem sprogene også omfatter (eller kan omfatte) en kulturel og etnisk sådan. ${ }^{7}$

\section{Don Quixote og gransen}

Don Quixote de la Mancha er et af litteraturhistoriens mest selvbevidste og ironiske værker. Parodien på antikke græske, mauriske, kastilianske og italienske genrer er allestedsnærværende. Ved siden af disse genre-parodier, der i sig selv er et studie værd, indeholder Don Quixote imidlertid også 
en ironisk skildring af det Spanien, som Cervantes levede i. Kastiliansk selvforståelse og mentalitet, kastiliansk politik, datidens sociale forhold og modreformatoriske kultur gøres gang på gang til genstand for forfatterens satire. Og det er her Bakhtins tese om de romanagtige genrers iboende »skæve sideblik " på den nationale kultur efter min mening bliver interessant at trække ind i analysen. ${ }^{8}$

Spanierne var vant til at tænke over, hvad der adskilte deres kultur og tro fra andre kulturer, især fra maurernes. Gennem århundreder havde den katolske og den mauriske kultur levet op og ned ad hinanden, præget og blandet sig med hinanden, domineret og ligget i strid med hinanden. Som et led i de succesive spanske kongers forsøg på at skabe en katolsk monokultur på den iberiske halvø, og som et led i den generelle modreformatoriske mobilisering af undersåtterne, bliver der fra $1492 \mathrm{og}$ frem ført en stadig mere hårdhændet spansk-katolsk identitetspolitik, der har til formål at skille de to kulturer og religioner ad, ikke mindst ved at udsætte jøder og maurere for forfølgelse, tvangskristning og udvisning. Det særlige ved den spanske identitetspolitik i det 16. århundrede er således, at den faktisk sker midt i og på grundlag af et flerkulturelt samfund. De andre er der allerede, med deres etnisk farvede skikke og klædedragt, med deres tro og deres kultur, midt imellem spanierne, og de har været der længe. For nogle spaniere blot som almindelige naboer, for andre som fjender og irritationsmomenter, men uanset hvilken relation man har til maurerne, bliver den almindelige spanier som en del af hans eller hendes egen formning til lydig, katolsk undersåt belært om sin egen identitet gennem en parallel bevidstgørelse om, hvad der adskiller katolikken fra muslimen. Da den modreformatoriske genkristning ikke bare drejede sig om religiøs disciplinering gennem indprentning af katolsk ortodoksi, men samtidig også greb formende ind i livsverdenen med anvisninger på, hvad der var god kristen levevis i modsætning til jødisk og maurisk levevis, ${ }^{9}$ kom den modreformatoriske genkristning i høj grad også til at handle om konstruktionen af en spansk kulturel identitet.

Cervantes synes at have haft et skarpt blik for sine landsmænds kulturelle selvbevidsthed og for spansk mentalitet i det hele taget. Dette blik var formentlig delvist muliggjort af den mauriske kulturs tilstedeværelse i Spanien, men flere Cervantes-forskere mener endvidere, at der hertil skal lægges det forhold, at Cervantes sad i algiersk fangeskab i 7 år. ${ }^{10}$ Ikke nok med at han længtes efter og grundede over sit tabte hjemland, han opnåede også et indgående kendskab til den fremmede og meget anderledes arabiske kultur og samfundsorganisering, hvad der giver anledning til at formode, at det, som jeg vil kalde Cervantes' »algierske erfaring ", ligefrem har været med til at præge hans blik på den spanske kultur og på 
spaniernes selvforståelse, herunder deres opfattelse af maurerne.

Første skridt i undersøgelsen af, hvordan den algierske erfaring har præget Cervantes, må være at kaste et blik på hans udvikling af datidens "romance fronterizo y morisco« - en specifik litterær tradition, som Don Quixote kan siges at repræsentere et kulminationspunkt indenfor. I en tilnærmelsesvis dansk oversættelse kan genrens benævnes: »den mauriske grænse-romance « eller »mauriske grænse-sang «. Genrens persongalleri og konfliktstof er hentet fra krigene mellem kristne og muslimer 1000 (ca) - 1492, og til genren regnes værker som det kastilianske (siden såkaldt »nationale«) helteepos Poema de Mio Cid (Digtet om min Cid, ca 1237), den anonymt udgivne El Abencerraje (navnet på en maurisk adelsmand, 1561), Ginés Pérez de Hitás Las Guerras civilis de Granada (Ridderkrigene i Grenada, 1564) og Miguel de Lunas Historia verdadera des rey don Rodrigo (Den sandfærdige beretning om kong don Rodrigo, 1566). Specialisterne i spansk guldalderlitteratur har længe diskuteret, hvorvidt disse romances fronterizos er maurofile eller maurofobe, ${ }^{11} \mathrm{og}$ der findes overbevisende argumenter for begge synspunkter. Dog synes flest at hælde til den opfattelse, at disse tekster i alt væsentligt forsøger at rehabilitere maurernes gode ry og rygte over for en stadig mere maurerfjendsk befolkning, ikke mindst ved at fremstille maurerne som lige så gode som de kristne. Dermed anerkendes maureren godt nok, men kun for så vidt som han eller hun ligner den kristne. Den kristne er den idealmodel, som maureren måles i forhold til, og som han eller hun som noget særligt for mange af disse grænse-fortællinger så skønnes at kunne leve op til. I Don Quixote rokkes der mærkbart ved denne kristne model og den kulturelle selvtilfredshed, der automatisk betragter det kristne menneske som maureren (og jøden) overlegen i både kulturel, religiøs og moralsk henseende.

Personskildringen i el romance fronterizo er til forskel fra personskildringen i Don Quixote idealiseret og stiliseret i overensstemmelse med romancens genrekonventioner. Både de kristne og deres mauriske fjender er smukke, høviske, noble og rene i troen. Den kradse realisme, den ironiske tone og det grotesk-komiske persongalleri, som karakteriserer den satiriske rammefortælling i Don Quixote, og som også stikker sit drilske ansigt frem i den høje stil i romanens indlagte fortællinger og maurerhistorie, findes ikke i den tidligere grænselitteratur. Dertil kommer, at maurerne og den arabiske kultur i Don Quixote forbindes med nye betydninger og værdier, som vi ikke finder i den tidligere grænselitteratur, nemlig penge, velstand og frihed på seksualitetens område. Den specifikt religiøse bestemmelse af maurerne som »de vantro « spiller således en langt mindre rolle i Don Quixote end i grænse-romancerne. I Don Quixote fokuseres der mere på 
den verdslige, kulturelle forskel. Endvidere har grænsen mellem maurere og kristne en mindre stabil status i Don Quixote end i grænse-romancerne. Cervantes viser ofte, at skillelinjen mellem kristne og maurere, akkurat som skillelinjen mellem sandt og falsk, kan være svær at trække, som det demonstreres gennem historien $\mathrm{i}$ andet bind om den landsforviste morisco Ricote og hans datter Ana Felix. ${ }^{12}$ Dels fordi mange maurere i virkeligheden var velintegreret i den spanske kultur. Dels fordi maurerne af frygt for repressalier, forfølgelse og udvisning bestræbte sig på at leve som de etniske kristne. Af disse og andre grunde lignede maurerne på Cervantes tid ikke nødvendigvis de vantro. Maurerne kunne både se ud som, leve og opføre sig som såkaldt »gammelkristne«. I hvert fald på overfladen. Don Quixote myldrer med etniske finter, der spiller på det etniske og trosmæssige alarmberedskab, som årtiers forfølgelse af jøder, maurere og kættere havde udstyret befolkningen med.

Hvor den ældre grænselitteratur således lidt forenklet sagt skildrer forholdet mellem maurere og kristne med udgangspunkt i grænsen som en skillelinje, der sætter et tydeligt skel mellem de rettroende og de vantro, de sande og de falske, de gode og de onde, skildrer Cervantes både i sine dramaer og i Don Quixote dette forhold med udgangspunkt i den sproglige, geografiske og kulturelle overskridelse af gransen og i det rum, som opstår mellem de to kulturer, idet grænsen overskrides. I Don Quixote som i det omkringliggende Spanien er denne overskridelse både en kulturel, demografisk-antropologisk kendsgerning, og en handling eller erfaring, som soldater, krigsfanger, renegater, handelsfolk gjorde sig - nogle frivilligt, andre ufrivilligt.

Hvad end den tidligere liminale litteratur kan siges at være maurofil eller maurofob, så gøres den spanske kultur aldrig til genstand for sådanne ironiske eksponeringer, som dem vi finder i Don Quixote, ikke mindst i dette værks bærende og helt centrale satire over det anakronistiske (feudale-ridderlige) efterslæb i samtidens Spanien. Den ideologiske usamtidighed i spansk kultur, mentalitet og samfundsliv, personificeret i den riddergale hidalgo don Quixotes mangel på realitetssans, er slet ikke noget tema i grænse-romancen.

Endelig adskiller Don Quixote sig fra den tidligere litteratur i kraft af det selvbiografiske indhold. Cervantes var fange hos den muslimske fjende i Algiers i 1575-1581, og denne erfaring spiller en afgørende rolle i hans forfatterskab og således også i Don Quixote, hvor flere kapitler i slutningen af bind 1 er helliget den selvbiografiske »Krigsfangens beretning «. Og når vi beører det selvbiografiske element Don Quixote, så bør det også nævnes, at Cervantes efter sin repatriering i 1581 udviser tegn på en identifikation med en specifik social og kulturel type i datidens Spanien: el soldado 
fronterizo eller el hombre de frontera. ${ }^{13}$ Grænsesoldaten var en person, der levede på og af grænsen mellem den kristne og den islamiske kultur, idet han tjente til livets opretholdelse enten ved at kæmpe på begge sider af troens frontlinje eller ved at handle med fjenden. Sådanne soldados fronterizos, om hvilke der forøvrigt findes et utal af legender og romancer, kunne have status både som helte og som landsforræddere - det sidste selvfølgelig fordi deres loyalitet var til salg. Interessant og tankevækkende er det imidlertid at notere sig, at disse soldater også kunne blive gjort til genstand for heltedyrkelse, ikke bare fordi de forsvarede og kæmpede for den katolske tro, men også fordi de modstod fristelsen fra den islamiske kultur. ${ }^{14}$ I datidens litteratur såvel som i virkelighedens verden var det langt fra et ukendt fænomen, at den muslimske fjende forsøgte at lokke de kristne soldater over på deres side ved at stille dem rigdom og skønne kvinder i udsigt. ${ }^{15}$ Og et hel specifikt begreb om heroisme opstod derfor omkring de kristne soldaters evne til at udvise standhaftighed over for de islamiske fristelser. Denne på en og samme gang historiske og litterære person med et ben i hver lejr, som både frygtede og var fristet af den muslimske kultur, denne liminale person, som Cervantes angivelig følte et vist slægtskab med, kan vi mærke i Don Quixote. Nærmere bestemt i den overraskende, fordomsfrie indstilling og interesse for arabere, maurere, renegater og muslimsk-maurisk kultur, som gennemtrænger Don Quixote og Cervantes forfatterskab i det hele taget.

\section{'Den algierske erfaring'}

Når man kender bare lidt til den grusomhed, som de kristne fanger og slaver blev ofrer for i arabernes og tyrkernes fangeskab, kan det undre, at fremstillingen af maurerne i Don Quixote er så positiv. Cervantes hørte ganske vist ligesom håndværkere, tømrere og bådbyggere til eliten blandt fangerne og blev således ikke udsat for den samme hensynsløse vold, som mange andre fanger, men han var dagligt vidne til, at andre blev udsat for tortur, lemlæstelser og smerter. ${ }^{16}$ Indtrykkene af denne vold og den fortvivlelse og frygt, som den skabte, har Cervantes skildret i sine dramaer: El trato del Argel (Livet i Algier) og Los banos del Argel (Fangekældrene i Algeriet), men i Don Quixote er de voldelige sider af den algierske kultur stærkt nedtonet. Der er dog $\mathrm{i}$ »Krigsfangens beretning « henvisninger til arabiske slaveejere, der spider deres kristne slaver på pæle, men disse forhold nævnes en passant, mens beretningen tildeler den sympatiske og venlige maurer Agi Morati, Zoraidas fader, en langt mere central plads i historien. På den baggrund forekommer det oplagt at antage, at grusomheden ikke var det eneste indtryk af den fremmede kultur, Cervantes 
tog med sig hjem fra Algier. ${ }^{17}$ De fremstillinger af den arabiske kultur og af arabere i Algier, som optræder i Don Quixote, stemmer endvidere godt overens med andre, historiske rekonstruktioner af livet i Algier.

Et af de kulturelle træk ved den muslimske befolkning i Algiers, som Cervantes må have været vidne til, var befolkningens og dens lederes pragmatisme på det kulturelle, etniske og religiøse område. Denne pragmatisme var formentlig en direkte effekt af det basale, materielle forhold, at Algier ligesom mange andre muslimske byer ved Middelhavet var et samfund, hvor jagten på økonomisk velstand udgjorde en væsentlig faktor for enkeltindividers stræben såvel som for den politiske regulering af samfundslivet. ${ }^{18}$ Algier var en multietnisk og multikulturel by, hvor folk fra alle dele af verden og dermed alle folkeslag kunne slå sig ned, forudsat at de konverterede til islam. Det var en by, hvor det var muligt selv for folk, der var født fattige, at opnå økonomisk velstand, militær og politisk indflydelse. Da Algiers ligesom Tripolis', Marrakesh', Tunis' og Fez' velstand i alt væsentlig var baseret på slavehandel og piratvirksomhed var det typisk som lønnet roer, siden for nogens vedkommende som kaptajn på et af de mange halv-officielle, halv-militære piratskibe, at almindelige mennesker, herunder et ikke uvæsentligt antal kristne renegater, kom til penge og magt. ${ }^{19} \mathrm{I}$ det osmanniske rige, som Berberiet på dette tidspunkt var en del, var handelsvirksomhed og investering af penge endvidere ikke begrænset af etniske og religiøse fordomme, hvilket var en af grundene til, at Algier på Cervantes tid var en langt rigere og mere ekspansiv by end byer af tilsvarende størrelse i det kristne Europa. At det islamiske samfund samtidig ikke var hæmmet af de europæiske feudale forestillinger om medfødte privilegier spillede også en rolle for den sociale mobilitet og $ø$ konomiske dynamik i Algier. ${ }^{20}$

Den algierske erfaring indebar således også en indsigt i den sociale mobilitets gunstige økonomiske og sociale virkninger for den enkelte. I »Krigsfangens beretning « omtales de kristne renegaters næsten eventyrlige politiske og militære karriere flere gange. Kontrasten til det etniske standsog privilegiesamfunds statiske natur må have slået Cervantes, hvilket hans udtalte opmærksomhed på de kristne renegaters opstigning i det sociale og militære hierarki i Algier kunne fortolkes som et tegn på. ${ }^{21}$

Som en tredje og sidste ingrediens i den algierske erfaring skal nævnes mødet med en målt med datidens kristne målestok udstrakt seksuel frihed. Homo- og biseksualitet blev tolereret og praktiseret offentligt, man kunne have op til fire koner, og skilsmisse var let at opnå. Cervantes har set direkte tegn på den større frihed på seksualitetens område. Det skete eksempelvis ofte, at arabiske og tyrkiske kvinder brød ind i fangekældrene for at ligge med de kristne mænd, hvad der ikke sjældent blev startskuddet 
for selvsamme kristnes konvertering til islam. ${ }^{22}$ I de to historier i Don Quixote, der foregår i Berberiet, spiller denne friere holdning til seksualiteten en central rolle. Krigsfangen nævner f.eks. flere gange, at de mauriske kvinder var meget indladende over for de kristne mænd.

Med til den algierske erfaring må imidlertid også regnes indblikket i kristent hykleri og dobbeltmoral. Som fange har Cervantes ikke kunnet undgå at få kendskab til den omfattende pengeøkonomi, der var opstået omkring udvekslingen af krigsfanger mellem muslimer og kristne - en økonomi, der degraderede de kristne krigsfanger, korsfarernes efterkommere, til profitable handelsvarer. Og det var vel at mærke ikke bare muslimerne, der tjente penge på de kristne krigsfanger og slaver. Også de munkeordner, der specialiserede sig $\mathrm{i}$ at samle ind til løsesummerne, og som drog til fjendeland for at aflevere pengene, lukrerede på denne handel med kristne sjæle. ${ }^{23}$

Som ufrivillig hombre de frontera har Cervantes oplevet et sammenstød mellem to kulturer, to samfundsordner. Lidt hårdt trukket op var det et sammenstød mellem på den ene side en materialistisk orienteret, dynamisk og pragmatisk kultur og på den anden side et kristent samfund, der selvfølgelig også frembød eksempler på økonomisk fortagsomhed og social mobilitet, men hvis økonomiske, sociale og politiske udvikling ikke desto mindre var hæmmet af gamle standsprivilegier, feudal regionalisme og generel uproduktivitet som følge af arbejdets lave prestige i befolkningen. Dertil kom de aristokratisk-imperiale ambitioner, der undergravede den nationale økonomi ved at lægge en dæmper på investeringslysten i forhold til den hjemlige produktion. Endvidere var Spanien et samfund, hvor kirken prædikede seksuel afholdenhed, hvor jomfruelighed forgudedes, mens den kvindelige seksualitet fremstilledes som satanisk og som den lige vej til fortabelse. Don Quixote-figuren rummer alle disse elementer i sig: den feudale mentalitet, der tilsiger ham at sætte æren over dyrkningen af jorden, ubehaget ved de samfundsmæssige forandringer (jvf. hans beskrivelse af sin egen samtid som en »jernalder « modsat de vandrende ridderes guldalder), den seksuelle askese, mangelen på indsigt i arbejdets nødvendighed $\mathrm{mm} .^{24}$

\section{Samtidsskildring - og det rene blod}

Forskellen mellem første og andet bind af Don Quixote sammenfattes ofte således: første bind er en dialog med datidens litterære genrer (ridderbøgerne, pastoralen, den sentimentale novelle, la novela morisca, el romancero fronterizo $\mathrm{mm}$.), andet bind er en diskussion af sociale, politiske og kulturelle forhold i Spanien og Middelhavsregionen, hvor osmannere 
og kristne gennem årtier havde kæmpet om herredømmet. Beskrivelsen er en anelse for kategorisk, al den stund der også optræder mange referencer til samtidsaktuelle problemstillinger og forhold i første bind, men som karakteristik af en tendens rummer den interessante perspektiver. Karakteristikken går iøvrigt godt i tråd med den gængse beskrivelse af romangenren som kendetegnet ved et fokus på nu- eller samtiden, det dennesidige, den almindelige verden osv. Ordene »dialog « og »diskussion « er også rammende for romangenrens forhold verden udenfor. Don Quixote afspejler ikke bare sin omverden eller sin samtid. Den udgør også en politisk intervention i sin tids sociale, etniske, kulturelle og politiske problemstillinger. Og nogle af de mest eksplicitte interventioner i samtiden angår spaniernes forvaltning af forholdet til maurerne (los moriscos) og til araberne i det hele taget.

Forud for Don Quixote går årtiers kamp mod de spanske maurere og mod deres »broderfolk «, osmannerne og araberne. Nærmere bestemt havde spanierne som følge af den katolske modoffensiv iværksat af Tridentinerkonciliet (1545-63), og som en konsekvens af muslimernes fremstormende hære syd-og østfra, skærpet linjen overfor landets mauriske befolkning siden $1550 \mathrm{erne}$. Et væsentlig symbol på den hårde linje var loven om det rene blod, »limpieza de sangre«, indført i 1550erne:

»... After centuries of neglect of racial questions, the pure-blood concern seemed to have flowed imperceptibly into all arteries of the country's life. [...] Pure blood [...] had become the guarantee of orthodoxy, of nobility, of the Spanish sense of honor « ${ }^{25}$

skriver E.D.Marcu om loven om det rene blod, idet han understreger, at denne lov afspejlede adelens, kleresiets og visse tredjestandsgrupper overvejende feudale forestillingsunivers, samtidig med at den gav ny næring til disse gruppers etniske og religiøse renhedsforestillinger. Mere specifikt skulle loven om det rene blod sikre, at kun gammelkristne spaniere uden jødisk og maurisk blod kunne få embeder og sidde i diverse råd og parlamenter. Loven indeholdt ydermere et forbud mod det arabiske sprog og mod alle former for etnisk farvede sæder og skikke. Dermed blev maurerne, i lighed med jøderne, tvunget til at spise (eller lade som om at de spiste) svinekød, for nu at give et eksempel, som Cervantes ofte henviser til.

På første side i Don Quixote fortælles det således om don Quixote, at han om lørdagen spiste: »duelos et quebrantos « - jammer og klage. »Duelos et quebrantos « var en ret bestående af svinekød, som angiveligt havde fået sit mærkelige navn, fordi det hed sig, at jøderne og maurerne 
jamrede og klagede, når de for at bevidne deres trofasthed mod katolsk tro og levevis nedlod sig til at spise svin. Hermed antydes det, at don Quixote måske i virkeligheden er en converso (konverteret jøde), der forsøger at skjule sine jødiske aner. En anden eksplicit allusion til den skærpede opmærksomhed på folks etniske tilhørsforhold dukker op i kapitel 9. I det på det tidspunkt endnu ikke oversatte arabiske manuskript står der, beretter morisco'en der i al hemmelighed oversætter teksten til »den anden forfatter «, at Dulzinea del Tobosa: »... havde den heldigste hånd i hele La Mancha, når det gjaldt om at salte svin. $\ll^{26}$ Når den mauriske oversætter ved læsning af denne oplysning braser i latter, skyldes det formentlig, at han genkender sit folks ihærdige forsøg på at overbevise omverden om deres »spanskhed «. Mao. Dulzinea er maurer, derfor har hun og fortælleren så travlt med at vise, at hun er god til at salte svin. I andet bind møder Sancho Panza og don Quixote en venlig herre, iført krumsabel, ved navn Diego Mirando. Ud fra sammenhængen at dømme må Dieo Mirando være en velassimilleret adelsmand af maurisk oprindelse. Efter at han har inviteret don Quixote og Sancho Panza inden for i sit hjem bekender han pludselig:

»Det sker, at jeg spiser hos mine naboer og venner, og ofte inviterer jeg dem; mine festmiddage er rene og pæne og ikke spor karrige. Jeg bryder mig ikke om sladder og tillader heller ikke, at der sladres i min nærværelse, jeg snager ikke i andres liv og gransker ikke andres gerninger..."

Hvorefter don Diego Miranda bedyrer, at han skam går til messe, at han tilbeder Jomfru Maria, og at han for at undgå beskyldninger om »hykleri« uddeler gavmilde almisser til de fattige. Men Cervantes har allerede med tegn, der var letafkodelig for samtidens læsere, afsløret den gæstfri og venlige adelsmands mauriske baggrund. Alle var ængstelige for at blive beskyldt for ikke at være rene i troen, men de nykristne nærede selvfølgelig en særlig udtalt bekymring for at blive udskreget som hyklere. Don Diego Mirandas sammenhængsløse, tilsyneladende umotiverede oplysninger om, at han da både spiser ude og inviterer folk hjem på middag, tjener også kun det formål at understrege, at han spiser som en gammelkristen. Ingen grund til at granske hans liv, der er intet at sladre om til øvrigheden. Don Diego Mirandas selvbeskrivelse, der egentlig mest af alt har karakter af et selvforsvar mod potentielle inkvisitionsanklager, er en tydelig effekt af den sociale og politiske praksis, der, frembragt af inkvisitionen, gik under betegnelsen »saber vidas ajenas", at kende andres liv -, og som i virkeligheden har meget tilfælles med et fænomen som angiveri. ${ }^{27}$ Således var 
inkvisitionen med sit fokus på almindelige, hverdagsagtige sæder og skikke med til at fremelske en vågen, men diskriminerende opmærksomhed over for livsverdenens almindelige praksisser. Dermed trængte de etniske renhedsforestillinger helt ind i almindelige menneskers mentalitet og kom til at forme og præge deres daglige liv og omgang med andre mennesker. Akkurat som don Diego Miranda, der i mødet med et par fremmede som don Quixote og Sancho Panza straks føler trang til at fortælle om sine helt almindelige sociale og religiøse vaner. Forestillingen om det rene, spanske blod havde ikke bare betydning på et bureaukratisk-politisk niveau.

Bortset fra de steder hvor historien direkte handler om maurere, lader Cervantes det typisk blive ved antydninger af sine personers mulige ikkespanske etnisk identitet. Han sår på den måde ofte tvivl om personernes sande, etniske identitet: er de crypto-jøder eller muslimer, selvom de siger det modsatte? Er deres kristne identitet sand eller en illusion? ${ }^{28}$ Denne tvetydighed afspejler den etniske realitet i Spanien på dette tidspunkt og udgør forfatterens kommentar til de succesive spanske regenters mislykkede forsøg på at skabe en ren spansk-katolsk befolkning.

Andre steder i Don Quixote er kommentarerne til spaniernes kamp mod muslimerne mere direkte. I den selvbiografiske »Krigsfangens beretning « indgår der en længere beskrivelse af tyrkernes og arabernes erobring af det spanske presidio i Tunis, La-Goleta frstningen i 1574..$^{29}$ Krigsfangen slutter beretningen på denne måde:

»Men mange mente, og heri var jeg enig, at himlen gjorde Spanien en særlig gunst og nåde ved at tillade, at dette arnested og skalkeskjul for ugerninger blev lagt øde, dette umættelige monster, denne svamp og snylter, der opsugede umådelige pengebeløb, som dér blev ødet bort til ingen verdens nytte og kun tjente til at bevare det lykkelige minde om, at den uovervindelige Karl d. V havde vundet stedet...« (bind 1, p. 448)

La Goleta-fæstningsværket i Tunis havde længe været et bekosteligt symbol på anden fase i den katolske generobring, som først dronning Isabella siden den hellige romerske kejser Karl d. 5. havde foretaget på nordafrikansk jord efter erobringen af den Iberiske halvø i 1492. ${ }^{30}$ Imidlertid skulle disse enklaver vise sig at blive »arnesteder for ugerninger «, fordi de soldater som i udgangspunktet deltog i dette cruzada ikke så meget var opflammet af troens ild, som de var opildnet af eventyrlyst og elementær berigelsestrang. Disse meget lidt religiøse motiver syntes også at have grebet de senere soldados fronterizos, der skulle bevogte frestningsværkerne til daglig, og som Cervantes refererer til ovenfor. Med »ugerninger« 
hentyder krigsfangen til de udstationerede soldaters hyppige økonomiske og seksuelle samkvem med den muslimske fjende uden for enklaven. At soldater tvunget af de usle forhold i presidio'erne ligefrem valgte at blive, som det hed, "professionel tyrker «"1 eller »renegat «, var nemlig ikke nogen sjælden foreteelse, og fænomenet repræsenterede et stigende moralsk problem for den spanske stat. ${ }^{32}$

Som et sidste eksempel på romanens mange interventioner i samtidens politiske problemer og på dens udstilling af spaniernes forståelse af sig selv og andre, skal en passage i første kapitel andet bind kommenteres. Det drejer sig om en diskussion blandt barberen, præsten og den (for en stund) forstandige don Quixote. Man diskuterer politik, statshensyn og regeringsmåder, man retter op på »misbrug « og »reformerede en skik og afskaffede en anden «. Med andre ord de tre venner er kritiske over for den måde, den regerende konge forvalter riget. Det understreges flere gange, at don Quixote deltager i denne diskussion som en mand, der er ved sine fulde fem. Men så sker der med eet noget, der får den gamle galskab til at bemægtige sig hidalgoen på ny. Præsten fortæller om »sikre efterretninger « fra hoffet, i følge hvilke Tyrken er på vej mod Spanien med en mægtig armada, hvorfor »hele kristenheden« er sat i højeste alarmberedskab. Beretningen om denne trussel fra Tyrken, der, som det fremgår, kun er på rygteplan, tricker don Quixotes galskab, og til hans venners store fortrydelse anbefaler den nu atter formørkede ridder kongen at indkalde de vandrende riddere:

»Det eneste, Hans Majestæt skal gøre, er at lade de offentlige udråbere beordre alle de farende riddere, der farter om i Spanien, til at samles ved hoffet på en fastsat dag, og selvom der kun kom et halvt dusin, kunne der være én blandt dem, der ene ville kunne ødelægge hele Tyrkens herredømme [...] Jeg [don Quixote] kommer til at dø som farende ridder, og Tyrken kan sejle hid og did, alt hvad han vil...«33

I første bind var det læsning af ridderbøger, der gjorde don Quixote gal. I andet bind vækkes den slumrende galskab til live af forlyderne om, at Tyrken er på vej med en mægtig flåde. Antydes der dermed en form for slægtskab mellem den tyrkiske trussel og ridderbøgerne ${ }^{34}$ Måske antyder Cervantes, at frygten for den store Tyrk efterhånden blot var lige så ureflekteret som troen på ridderbøgernes usansynlige historier. Vi ved, at Felipe d. 3. spillede på frygten for tyrkerne, da han skulle begrunde den endelige udvisning af de sidste $\$ 900.000$ maurere « i Spanien i 1609, og andet bind af Don Quixote må være skrevet efter 1609. ${ }^{35}$ Men truslen 
fra tyrkerne var efter alt at dømme ikke den virkelige, politiske årsag til udvisningen ${ }^{36}$. Mere sandsynligt er det, at den etniske uddrivelse repræxsenterede en mulighed for at slå et slag for katolsk ortoksi og overlegenhed, og at den således set fra Felipe d.3s og hans rådgiveres side var et forsøg på at genoprette og forfægte en skrantende kastiliansk styrke og prestige. Den spanske armadas nederlag til englænderne i 1588 var stadigvæk i frisk erindring. Hvad spanierne tabte udadtil til protestanterne og andre måtte vindes indadtil ved at smide de gamle ærkefjender maurerne ud. Og kunne man spille på den ældgamle frygt for Tyrken, ville udvisningen møde forståelse. Hvad den i meget vid udstrækning også gjorde.

Uanset hvad der måtte være om og ligge i sammenhængen mellem den quixotiske galskabs genopblussen og tyrkerygtet fra hoffet, så er det en kendsgerning, at de tre venners fornuftige samtale om Spaniens interne politiske problemer (magtmisbrug, vanrøgt) afbrydes af lige præcis rygtet om tyrkernes snarlige angreb samt af den galskab, som i samme øjeblik griber don Quixote. Akkurat som ville Cervantes sige, at opmærksomheden omkring de nationale problemer tilsidesættes af Spaniens konstante fokus på de ydre fjender, som landet havde fået som følge af sin imperiale fremfærd.

\section{Spanien set fra den anden kyst}

At kulturelle og politiske forhold ses med »et sidelæns blik « i Don Quixote bliver helt tydeligst i de to fortællinger, der direkte omhandler maurere, nemlig » Krigsfangens beretning « og Ana Felix' historie fra første henholdsvis andet bind. Her installeres vi som læsere ikke bare i krigsfangens liminale perspektiv på sociale og kulturelle forhold i Spanien. Vi presenteres også for et arabisk blik på Spanien. Ovre fra den anden kyst kigger fjenden tilbage på »os", mens vi kigger på »ham« og på »hende«. Den gensidige spejlings- og eksponeringsproces i disse maurer-historier udvirker en påfaldende komplicering og relativering af de dikotomier og strukterer, som forholdet mellem »spaniere « og »maurere « typisk gribes i på Cervantes' tid: maurer $=$ falsk $=$ ond og kristen $=$ sand $=$ god.

De to historier fortæller hver deres beretning om mauriske kvinder, der ønsker at leve i Spanien - som katolikker. Den ene, Zoraida (fra første bind) har siden barnsben i al hemmelighed troet på Jomfru Maria og ønsker nu som voksen at flygte med spanske krigsfanger til Spanien for dér at konvertere til katolicismen. Den anden, Ana Felix, er født og opvokset i Spanien, er troende katolik, men er alligevel blevet udvist i 1609. Da vi møder hende har hun sneget sig illegalt tilbage til Spanien for at hente den formue, som faderen gravede ned på deres jord, før de 
forlod landet. Ana Felix vil i lighed med sin far Ricote - Sancho Panzas gamle nabo - gerne tilbage til Spanien. Det påtvungne eksil i Berberiet har været fuld af lidelser.

Zoraida og Ana Felix har liminaliteten til frelles. Begge krydser de grænsen mellem den muslimske og den katolske verden. Hvilke perspektiver på spansk og arabisk kultur etableres der i det grænsefelt mellem de to kulturer, som passagen åbner? Lad os starte med at se på, hvordan de to kulturer og samfundsordner sættes op over for og gensidigt belyser hinanden.

Ruy Pérez de Viedma - krigsfangen - redegør nøje for sine sociale og familiemæssige baggrund, før han starter beretningen om Algier og Zoraida. Denne redegørelse bærer præg af en præcis forståelse af sociale, $ø$ konomiske og familiemæssige mønstrer i det 16. og det 17. århundredes Spanien. Viedma-familien inkarnerer, hvad vi i dag ville kalde: »den gamle (feudale) orden ${ }^{37}$ i det daværende spanske samfund. Familiens rigdom er baseret på jordbesiddelser, og retten til at besidde jord er knyttet til faderens standsmæssig identitet som hidalgo. Endvidere understreges det kraftigt, at faderen ikke drager omsorg for, at familieformuen enten stabiliseres eller vokser. Ødsel og spendabel som han er, bruger faderen tværtimod løs af pengene uden tanke på den næste generation. Imidlertid gribes han pludselig af bekymring for sine børns økonomiske fremtid og deler derfor sin formue i fire lige store bidder - en bid til hver af de tre brødre og en til ham selv. På grund af den skrumpne formue kræver han endvidere, at de tre sønner vælger at blive handelsmænd eller præster. Alle sønner tvinges hermed ud i en mindre stabil virkelighed end den, som faren selv er vokset op i og har levet $i$, hvor godset blot er gået $i$ arv fra generation til generation. Ruy Perez - den ældste - vælger at tjene til livets ophold som soldat, Juan vælger at studere, og den yngste unavngivne bror drager som handelsmand til den nye verden, hvor det lykkes ham at blive velhavende. Takket være regelmæssige pengeforsendelser fra denne fortagsomme søn i den nye verden kan faderen opretholde sin uvirksomme og bekostelige tilværelse i Spanien, og sønnen Juan kan studere til dommer. Krigsfangens familie danner således et kondenseret billede af typiske økonomiske og sociale træk ved Spanien i slutningen af det 16. århundrede: en feudal orden, hvor en jordbesiddende adel lever af eller rettere: forarmes som følge af sine ikke-produktive formuer og jordbesiddelser, mens landets økonomi som sådan er baseret på guldindtægter fra og handelsvirksomhed i den nye verden.

Et andet bemærkelsesværdigt forhold ved Ruys familie er, at moren er død. Mødrene er i det hele taget påfaldende fraværende i historierne i Don Quixote. ${ }^{38}$ Her deler Ruy skæbne med den mauriske Zoraida, hvis mor 
også er død, men - hvilket er af stor betydning for historien - Zoraida er blevet ammet og opfostret af en kristen kvinde, der opdrog hende i den kristne tro. For Zoraida er katolicisme og moderlighed således flydt i eet, og hun omtaler konsekvent sin konvertering til katolicismen som en forening med jomfru Maria. Gennem Zoraidas forventninger til den katolske kirke formuleres der dermed en langt fra enestående teologisk og institutionel utopi om den katolske kirke som »moderkirken «, rummelig og altfavnende, også over for såkaldt nykristne. En utopi, der blandt andet modsiges af de meget strenge inkvisitionsforhør og offentlige bodsudøvelser, som frigivne kristne krigsfanger og slaver skulle igennem, før de kunne blive genoptaget i den katolske kirke. At det i Don Quixote altid fremstilles som om, at renegaterne problemløst indlemmes i den katolske kirke ved deres tilbagekomst til Spanien, skal ligesom Zoraidas billede af katolicismen henregnes under bogens utopiske dimension. Med til denne utopi hører også fantasmet om maurens frivillige konvertering til katolicisme, i Don Quixote konkret realiseret i Zoraidas følelsesmæssigt motiverede kristning og i Ana Felix' ligeledes inderlige katolske tro. Disse utopiske elementer eller dette utopiske blik på Spanien og spansk kultur er i virkeligheden beslægtet med det mildt ironiske blik, som udgør den implicitte forfatters gennemgående kendemærke. Det utopiske, naive blik, her konkret geografisk lokaliseret i Nordafrika og inkarneret i den anden, artikulerer gennem den (iscenesatte) nærmest barnlige uvidenhed om den historiske virkelighed og den katolske kirkes sande ansigt, en kritik af den modreformatoriske kirkes ekskluderende, diskreminerende og puristiske forvaltning af katolicismen. Det sidelæns, reflekterede og kritiske blik på den egne kultur manifesterer sig ikke blot som satire og ironi, men kan også udtrykkes i utopiens indirekte udsagn om det gode alternativ til det eksisterende, i dette tilfælde en tolerant og inkluderende kirke.

Der foregår endvidere gensidige eksponeringer af de to forskellige kulturer på to andre for enhver kultur meget centrale områder: det generationsmæssige og det kønsrollemæssige område. Som en (imaginær) eksemplifikation af kulturelle forhold i de to respektive kulturer sætter krigsfangens beretning en markant modsætning op mellem far-barnrelationen i den spanske henholdsvis den arabiske verden. I den lavadelige spanske familie »bestjæler « faren sine autoritetstro sønner ved sin aristokratisk-hedonistiske uvirksomhed og manglende sans for pengenes virkelighed. I den arabiske familie bestjæler datteren sin far, hvis magt hun gennem en hel serie af bedrag og en endelig total fornedrelse, demonstrerer alt andet end respekt for. Krigsfangen affinder sig med den situation, som farens ødselhed har placeret ham i; Zoraida bryder op og river sig løs fra den struktur og den kultur, som hun er født ind i. Hun 
forfølger med en - forekommer det - næsten ubarmhjertig konsekvens og ildhu sit egoistiske mål i tilværelsen, der interessant nok er at blive katolik. Dermed skaber historien nogle overraskende sammenkoblinger på tværs af de moralske diktomier, som forskellen mellem maurere og kristne typisk blev forstået i på daværende tidspunkt. Zoraida behandler sin kærlige fader respektløst, hun lyver over for ham, bestjæler ham, krænker og nedværdiger ham i andres påsyn og hendes dybeste ønske i tilværelsen er at blive katolik. Katolicisme, falskhed og datterlig ulydighed kobles således sammen i Zoraidas person. Sammenkoblingen træder frem, fordi beretningens distribution af positive og negative valoriseringer ikke sker med udgangspunkt i den velkendte dikotomi (muslim=falsk, kristen=sand), men derimod med udgangspunkt i det liminale felt mellem de to kulturer, hvor begge kulturer er repræsenteret, og hvor det således er muligt for fortælleren såvel som for læserne at få indblik i skiftevis det kristne og det muslimske perspektiv på spørgsmål om, hvad den rette tro, den sande troende, og den bedste verden er. For eksempel giver historien os mulighed for at mærke farens sorg over at miste Zoraida til katolikkerne, og den udmaler ligeledes hans forestilling om, hvordan der ser ud ovre på den anden kyst:

»Hvorfor tror I, kristne, at denne slette kvinde har lyst til, at I skal give mig friheden? Tror I, at det ker af respekt for mig? Nej, bestemt ikke; hun gør det tværtimod, fordi min tilstedeværelse forstyrrer hende, når hun vil sætte sine slette lyster i værk; I skal heller ikke tro, at hun er blevet bevæget til at skifte religion, fordi hun mener, at jeres tro er vores religion overlegen, men fordi hun ved, at i jeres land er man mere fri til at være uanstændig end i vores. $\aleph^{39}$

Og Zoraidas erotisk indladende optræeden over for krigsfangen, dét at hun kysser ham lige for øjnene af sin far, mens han sidder bastet og bundet til skibsmasten på det skib, der skal føre hende og krigsfangen til Spanien, giver faktisk læseren grund til for en stund at overveje, om faren måske har ret. En af de læresætninger, som Krigsfangens beretning antyder, synes således at være, at: »det som vi forestiller os om de andre, forestiller de andre sig også om os «. I det liminale felt mellem de to kulturer, som krigsfangens beretning er skrevet i og fortæller om, opløses de nationale opfattelser af den egne kulturs overlegenhed (og den dertilhørende opfattelse af den fremmede kultur som mindreværdig) i et konstant skiftende perspektiv. Snart ser vi maurerne gennem de kristnes øjne, snart de kristne gennem maurernes øjne. Begge kulturer ses således fra den andens ikkeidentifikatoriske synspunkt. 
De markante forskelle i generationsforholdet i den arabiske henholdsvis den spanske kultursammenhæng skal også ind her. Som nævnt krænkes Agi Moratis faderautoritet gennem Zoraidas bedrag, tyveri og efterfølgende eksplicitte fornedrelse af ham. Denne adfærd er fra Zoraidas side motiveret af det altoverskyggende ønske om at blive forenet med den store Moder. At Moderen i dette tilfælde er sammenfaldende med Jomfru Maria lader vi for en stund ude af betragtning, idet det jo er tydeligt, at for Zoraida representerer jomfru Maria et modersurrogat. Til dette moderbillede knytter der sig for Zoraida diverse signifikante forestillinger om almagt. Hun er overbevist om, at Jomfru Maria vil kunne løse alle hendes problemer (finde en mand, der kan forsørge hende eksempelvis), så såre hun sætter sine fødder på spansk grund. I en psykoanalytisk terminologi kunne man tale om Zoraidas billede af den almægtige, altfavnende og nærende moder som en reminiscens af barnets præ-ødipale symbiose med moderkroppen. Her har endnu ikke været nogen (symbolsk) far på spil, her er endnu ikke introduceret en symbolsk orden, der skiller barnet fra moderen, ondt fra godt, rigtigt fra forkert, sandt fra falsk, ikke mindst ved at introducere andre hensyn i barnets bevidsthed end det egoistiske (og helt ureflekterede) hensyn til dets egen behovstilfredsstillelse. For Zoraida eksisterer der kun et ønske at tage hensyn til: hendes genforening med moderkroppen, koste hvad det vil. Hvor Zoraida har for lidt respekt for sin far (og den sociale og moralske orden, hun er indfældet i), har krigsfangen for stor respekt for sin far og hans orden. Hvor Ruys far og dermed den gamle sociale orden svigter den yngre generation, idet faren fastholder en livsform, som er uforenelig med den nye økonomiske virkelighed, svigter Zoraida sin far til fordel for foreningen med moderen. Krigsfangen adlyder sin ødsle, uansvarlige og økonomisk inkompetente fader; Zoraida trodser sin omsorgsfulde og økonomisk dygtige far. I total ligegyldighed over for hans ret (bl.a. til den formue han selv har oparbejdet) tilraner hun sig hans juveler, perler og guldmønter og bruger dem til sit eget formål.

Den hermeneutiske præmis for denne analyse af Zoraida-figuren og krigsfangen har lige fra begyndelsen været, at de og den familiestruktur, som de er indfæeldet $i$, personnificerer to forskellige samfundsordner. Ruy Perez de Viedmas familie personnificerer den feudale, patriarkalske orden, hvor faderens myndighed er legitimeret af et transendentalt forankret, socialt hierarki, der eksisterer forud for den enkeltes konkrete realisering (eller misligholdelse) af myndigheden, mens Zoraidas familie inkarnerer en verden, hvor autoriteter tilsyneladende ikke i samme udstrækning som i »Den gamle verden« er metafysisk legitimerede. Her kan det individuelle behov, eventyrlysten, egeninteressen i form af piratvirksomhed og anden 
form for tyveri udfolde sig og foregå forholdsvis uhindret af moralske og juridiske magtstrukturer. Algier - en havn for berigelseslystne eventyrer fra alle egne af verden - var en »ny verden«, ikke politisk, socialt og juridisk organiseret som Spanien eller som Konstantinobel for den sags skyld. Ikke uden grund opfattede osmannerne Nordafrika som en række, underlegne og uregulerede vasalstater - et territorium, kolonier, ikke ulig den måde spanierne opfattede deres nye verden, Peru og Mexico, på.

Zoraida er smuk, og mange kommentatorer har i hende set et symbol på slavens eller fangens drøm om frelse og udfrielse fra trængslerne i de humske fangekældre i Algier. Med til hendes tilsynekomst i Krigsfangens beretning hører imidlertid også, at hun er et symbol på en økonomi og en samfundsmæssig orden baseret på ran og begær. Hendes flugt til Spanien indebærer ikke overraskende en sublimering af begæret i religiøs askese.

\section{Det algierske begers sublimering}

Zoraida ændrer - ligesom Ana Felix - identitet, da de krydser grænsen til den kristne verden. Ændringen afspejler sig også i krigsfangens forandrede relation til hende. Mens hun er i Algier fremtræder Zoraida således:

»Det ville være for meget, hvis jeg skulle beskrive den store skønhed, ynde og prægtige og kostelige pryd, hvormed min elskede Zorayda viste sig for mine øjne; jeg vil kun sige, at der hang flere perler om hendes skønne hals og fra hendes øren og hår, end hun havde hår på hovedet. Om anklerne, som var utildækkede efter deres skik, bar hun to carcaj'er [...] af det pureste guld og med mange indfattede diamanter, som hendes far vurderede til ti tusinde algierske guldmønter, efter hvad hun siden fortalte mig, og dem, hun bar om håndledene, var lige så værdifulde. Perlerne var af en høj karat, og der var mange [...] Zoraydas far havde ry for at eje mange perler, der var blandt de fineste i Algier, og desuden besad han mere end to hundrede tusinde spanske escudos, og alt det herskede hun over... $\ll^{40}$

Beskrivelsen er gennemtrængt af en besættelse af penge. Zoraydas perler og juveler registreres minutiøst, og deres markedsværdi på såvel det algierske som det spanske markede er omhyggeligt angivet. Zoraydas skønhed og erotiske tiltrækningskraft er uadskillelig fra hendes rigdom. I krigsfangens øjne forlener dobbeltheden af skønhed og rigdom samtidig Zorayda med en strålende almagt - som om hun kunne byde på alle tænkelige - fysiske, æstetiske og seksuelle - former for nydelse. Denne 
hedonistiske almagt bliver så meget desto større, som at hun samtidig er i besiddelse af en stor erotisk frimodighed. Allerede ved sit første møde ansigt til ansigt med krigsfangen lægger Zorayda armen om krigsfangens hals. Samme erotiske frimodighed viser hun på skibet, der skal føre hende og de spanske krigsfanger til Spanien, hvor hun lader krigsfangen omfavne sig lige op i farens åbne ansigt, uden at hun, som der står, gjorde mine til at forsvare sig, klagede eller forsøgte at undvige. Dertil kommer en afgørende omvending af det typiske vestlige-kristne kønsrollemønster, hvor den passive kvinde afventer den aktive mands initiativ. I Algier er aktiv-passiv rollerne byttet om. Zoraida er i lighed med den anden mauriske pige Ana Felix mere snarrådige og handekraftige end mændene - i maurerland er det således generelt mændene (de kristne), der er svage og passive, fordi fanget og indespærrede, mens kvinderne agerer, ordner, lægger planer osv.

Den erotiske frimodighed, handlekraften, rigdommen og den $x$ ggende skønhed forsvinder imidlertid, da Zoraida kommer til Spanien. Rollefordelingen mellem kønnene byttes om, og kvinden indtræeder i den passive position, mens manden forvandles fra et passivt begærende subjekt til beskyttende forvaltere af denne ellers så selvstændige kvindes dyd og frelse.

Ana Felix' historie fra andet bind følger stort set samme skema. Mens hun og hendes kristne elskede Don Gaspario befinder sig i det påtvungne eksil i Nordafrika vendes også deres relation på hovedet. Don Gaspario bliver »feminiseret « først af kongens (og stortyrkens) homoseksuelle tilbøjeligheder for smukke unge mænd som ham og siden, da han som et led i Ana Felix' snarrådige flugtplan forklædes som kvinde og spærres inde i kongens harem. Muligheden for og evnen til at handle sig ud af fangeskabets påtvungne passivitet er også i denne historie placeret hos kvinden. Så såre Ana Felix er tilbage i Spanien lægger hun imidlertid afmægtigt sin egen og sin elskedes skæbne i de mandlige øvrighedspersoners hænder. Om de har magt til at skaffe hende opholdstilladelse melder historien imidlertid intet om.

Undervejs over havet fra Nordafrika til Spanien har Zoraida mistet sine penge. Dermed er de ydre, materielle tegn på hendes hedonistiske andethed borte. Siden hører vi, at der kun er rester tilbage af hendes tidligere så mangefarvede og potente skønhed. Nu fremtræder hun tilhyllet, ude af stand til at tale sproget, henvist til en passiv og afmægtig position under manden og kun optaget af troens askese. Zoraidas assimilation i den spanske kultur har betydet en afvikling af hele den farlige hedonisme, skønhed og handlekraft, som hun på en og samme gang udstrålede og inkarnerede, mens hun stadigvæk var den algierske anden. 
De to liminale fortællinger i Don Quixote bærer vidnesbyrd om en forfatter, der kendte den arabiske kultur på nært hold, og selvom der i portrættet af disse falliske mauriske skønheder er ansatser til orientalisme avant la lettre, efterlader historierne alligevel et indtryk af, at Cervantes navigerer uden om både maurofobiens og maurofiliens forenklinger. Cervantes hverken hader eller dyrker, frygter eller ser ned på den arabiske kultur og de spanske maurere - han bruger deres anderledes kultur litterært og intellektuelt. Den egne kultur bliver tydeligere i lyset af den anden kultur.

\section{Konklusion: Romanen som europaisk kunstart}

Lad mig runde af med at knytte en forbindelse til Milan Kunderas Romankunsten, hvori Don Quixote spiller en væsentlig rolle. »Romanen er Europas værk « skriver Kundera, og den første roman er ifølge ham Don Quixote. Det særlige ved Europas udvikling er, at sekularisering og oplysning lige siden renæssancen har forsøgt at fortrænge den religiøse verdensanskuelse, og at denne verdensdel samtidig har fostret en litterær genre - den europxisk roman - kendetegnet ved en udforskning af den menneskelige livsverden set i lyset eller skyggen af Guds død så at sige. Romanen og således også Don Quixote handler om menneskets liv i en gudsforladt verden:

»Da Gud forlod den plads, hvorfra han havde styret universet og dets værdiorden, skilt godt fra ond og givet hver ting en mening, trådte Don Quijote ud fra sit hus, og han kendte ikke verden igen. Den fremtrådte pludselig, nu hvor den øverste dommer var borte, med frygtelige flertydighed; den guddommelige, eneste Sandhed opløstes i relative sandheder i hundredevis, som menneskene delte imellem sig. Således fødtes nyere tids verden og med den romanen, dens billede og model. $\ll^{41}$

Den forudgående kulturhistoriske analyse af Don Quixote som en roman, der udspringer af, udforsker og handler om bevægelser henover den på en og samme gang geografiske, etniske og kulturelle grænse mellem islam og kristendom kan passende bringes i dialog med Kunderas forståelse af romanen som en oplyst og europxisk kunstart. Den forudgående Bakhtininspirerede analyse af den kulturelle liminalitet i Don Quixote kunne forklare denne romans udbredte flertydighed, »Sandhedens opløsning i relative sandheder ", som betinget af udveksling, konflikt, påvirkning og interanimation mellem de forskellige europæiske kulturer, men så sandelig 
også mellem disse og kulturer uden for Europas grænser. Som tidligere muslimsk land med en stor maurisk befolkning og i kraft af den geografiske tæthed til Nordafrika udgjorde Cervantes' Spanien det daværende Europas ikke særlige stabile grænse mod den arabisk-islamiske kultur. Når ingen roman siden Don Quixote har kunnet eller tilsyneladende har haft som ambition at opbyde den samme grad af relativisme, flerstemmighed og satirisk udlevering af ethvert forsøg på at finde en højere mening med tingene, handlingerne og begivenhederne, da skyldes det måske, at de europæiske stater har lukket sig mere og mere omkring deres nationale kulturer, hvorved også grænsen mellem det kristne Europa og den muslimske verden lige er blevet trukket stadig kraftigere op, samtidig med at magtbalancen mellem den vestlige og den arabiske verden er tippet definitivt over i Vestens favør.

\section{Noter}

1 Nærværende artikel er et sammendrag af to kapitler i et større bogprojekt om Cervantes' forfatterskab, hvori den fiktive historie om fundet af det arabiske manuskript, der angivelig skulle ligge til grund for Don Quixote, gøres til genstand for litteratur- og kulturhistoriske læsninger. Desværre er det ikke muligt at komme ind på dette emne inden for denne artikels rammer. Analysen vil således fortrinsvis koncentrere sig om romanens tematiske niveau.

2 Den amerikansk-columbianske hispanist Maria Antonia Garcès har også introduceret dette begreb om liminalitet i sin bog Cervantes in Algiers. A Captive's Tale, Nashville 2002. Heri beskriver hun med udgangspunkt i antropologen Victor Turners teori om overgangsritualer liminalitet som: »an interstructural situation that constitutes transitions between states« (pp. 190-191). Garcès beskriver med tanke på Cervantes’ ophold som krigsfange i Algiers fangeskabet som en liminal situation, fordi fangen er afskåret fra sin vante sociale og kulturelle ramme samtidig med, at han/hun ikke ved, hvad der skal ske, når og hvis friheden genvindes. At befinde sig på grænsen mellem kulturer og lande er en anden form for liminal situation. Cervantes havde prøvet begge situationer.

3 Don Quixote's danske oversætter Rigmor Kappel Schmidt har à propos »grænsen« ved flere lejligheder skrevet og talt om overskridelsen af den etniske grænse, af kønnets grænse, af kapitlets og af grænsen mellem rammenfortællingen og de indlagte fortællinger.

4 »In essence this discourse always developed on the boundary line between cultures and languages", M.M.Bakhtin: The Dialogical Imagination. Four Essays, Austin 1981, p. 50.

5 »it [the novel] owes its emergence to a specific rupture in European civilisation [that is] when socially isolated and culturally deaf semipatriarchal societies... [were replaced] by a multitude of different languages, cultures and times [... this became a decisive factor in the novel's life and thought«. Op.cit., p. 9.

6 »... the Latin literay word viewed itself in the light of the Greek word, through the eyes of the Greek word; it was from the very beginning a word 'with a 
sideway glance', a stylized word enclosing itself, as it were, in its own piously stylized quotation marks...«, op.cit., p. 61.

7 Denne betoning eller forskydning fra det specifikt sproglige til det bredere kulturelle felt falder inden for rammerne af Bakhtins egen teori. Dels taler han flere steder om »hybrid cultures « og om »boundary lines between cultures and languages «, dels ligger det implicit i hans litteraturteori, at sproget, stilen og de litterære genrer er bærere af eller udtrykker verdensanskuelser. Det vil sige kulturelt farvede opfattelser, forestillinger og værdier.

8 Maurisk kultur var langt ind i det 13. og 14. århundrede den kristne kultur på den iberiske halvø overlegen. Væsentlige værker fra den antikke græske filosofi blev bevaret og oversat til arabisk og derfra til latin og kastiliansk af mauriske lærde. Maurerne var i flere henseender en slags kulturelle forbilleder, især for unge, ambitiøse og modebevidste kristne lærde, der yndede at klæde sig som maurerne og indrette deres hjem efter maurisk skik.

9 Se herfor: Jean-Pierre Dedieu: L'administration de la foi. L'inquisition de Tolède (XVIième-XVIIIième siècle), Madrid 1989.

10 Den nulevende spanske forfatter Juan Goytisolo hævder i sin roman Cronicas sarrancinas (Saraseniske historier, 1991), at det billede af Spanien, som Cervantes tegner i Don Quixote, er formet, mens han sad i fangeskab på den anden side af grænsen, i Algier: "The Cervantine obra is conceived from the other shore - that of the excluded and rejected by Spain [...] Cervantes elaborated his complex and admirable vision of Spain while in prison in Africa Territory. « Citeret efter Maria Antonia Garcès, p. 17.

11 For denne diskussion se: Luce Lopez-Baralt: "The Two Sides of the Coin", Islam in Spanish Literature. From the Middelage to the Present, Leiden 1992.

12 Især var maurerne i La Mancha-regionen, hvor Don Quixote skal forestille at foregå, meget velintegrerede og de klarede sig godt socialt og økonomisk. De lokale myndigheder i La Mancha forsøgte også ved flere lejligheder at beskytte maurerne mod kongens diskremineringspolitik. Se herfor: Carla Rahn Phillips: »The Moriscos of La Mancha. 1570 - 1614«, in The Journal of Modern History, Vol. 50, No 2. 1978.

13 Miguel de Cervantes Saavedra hed oprindelig kun Cervantes til efternavn. »De Saavedra « kom først til, efter at han var vendt tilbage fra Berberiet. Navnet Saavedra havde mange konnotationer på Cervantes' tid. Det var kendt fra en middelalderlig folkevise om krigene mellem maurerne og de kristne, det optræder i Hitas Guerras civiles de Granada og udgjorde samtidig slægtsnavnet på en kendt og meget indflydelsesrig spansk familie, der havde slået sig ned i Sevilla omkring 1351. Garcès opsummerer betydningerne i navnet Saavedra således: »... Saavedra is an incarnation of limit [...] Saavedra evokes the cultural and geographical frontiers between the Christian and the Muslim worlds. These frontiers not only refer to the boundaries and barriers between geopolitical units, countries, nations, or communities, but also to those between cultural domains or 'territories', philosophical or religious traditions, linguistic idioms, and languages in general «, Maria Antonia Garcès, p. 190.

14 Op.cit.

15 Om de fristelser, som de islamiske kulturer rundt om Middelhavet repræsenterede for kristne mænd, se: Bartholomé og Lucile Bennassar: Les Chretiens d'Allah. L'histoire incroyable des rénégats au XVIe-XVIIe siècle, Paris 1989. Ifølge Benassar fik ny-muslimer en betragtelig startkapital overrakt i forbin- 
delse med konverteringsceremonien. Dertil kom endvidere udsigten til en tilværelse i en kultur med friere og meget mindre syndsorienteret indstilling til seksualiteten samt muligheden for økonomisk og social avancement.

16 Cervantes sad ikke indespærret i fangekældrene hele tiden, men havde lov til at gå frit omkring inden for Algiers bymurer inden for specifikke tidsrum. Bl.a. derfor var det muligt for ham at kaste sig ud i tre mislykkede flugtforsøg.

17 I Cervantes' gode ven og medfange, den portugisiske historiker og glødende katolik Antonio de Sosas Topografia e historia general de Argel, kan man registrere en dobbelthed i synet på den algierske kultur, der til et vist punkt kan genfindes hos Cervantes. På den ene side skildrer Sosa torturen og lemlæstelserne af de kristne fanger, og måden han dvæler ved og udpensler disse grusomheder, underbygger tidens mange dæmoniserende fremstillinger af islamisk kultur. På den anden side opregner Sosa med stor interesse sproglige, demografiske, etnografiske, teknologiske og handelsmæssige forhold i Algier. Garcès hævder à propos denne dobbelthed, at Sosas dæmoniserende beskrivelser af islamisk kultur var betinget af, at han var i fangeskab hos nogle særlig grusomme slaveejere og herskere. For mange af de andre europæiske lærde som f.eks. Cervantes, der gennem fangeskab kom til at leve i tæe kontakt med muslimerne, var det imidlertid svært: »to demonize Islam in such a crude way. The case of Antonia de Sosa is a special one «. Dog formåede Sosa altså også at skrive et værk om Algier, der påtrods af disse dæmoniserende tendenser fremtræder som: »a balanced work of investigation that shows a careful and impartial historian at work «. Maria Antonia Garcès, p. 88.

18 De nordafrikanske muslimers pramatiske indstilling til de kristne fangers og slavers tro manifesterede sig bl.a. derved, at slave- og fangeejerne opfordrede de kristne til at indrette kirker og afholde messer som hjemme i Spanien. Slaveejerne betalte endog spanske munke og præster for at komme til Nordafrika og etablere katolske menigheder i fangekældrene. Ofte deltog araberne og tyrkerne selv i de katolske messer formentlig af ren nysgerrighed, i følge Ellen G. Friedman Friedman forklarer de muslimske araberes religiøse tolerance som et udslag af økonomisk beregning: jo mere tilfredse de kristne slaver og fanger var, jo mere arbejdede de, og jo mere ville slaveejeren tjene. Dette var angivelig også årsagen til, at man opfordrede de kristne fanger til at åbne udskænkningssteder i fangekældrene - beværtninger som araberne uanset det islamiske forbud mod indtagelse af alkohol selv forsynede med vin. Se herfor: Ellen G. Friedman: »The Exercise of Religion by Spanish Captives in North Africa «, in Sixteenth Century Journal, Vol. 6, N.1, April 1975.

19 Disse penge blev sjældent investeret i decideret produktion, men skabte dog en så stor efterspørgsel på mad, goder og værdier i byen, at Algier oplevede en stor befolkningstilvækst i løbet af det 16. århundrede, mens også handelslivet og småindustrien i byen blomstrede. Se herfor: Carroll B. Johnson: Cervantes and the Material World, Chicago 2000.

20 Hvad dette fravær af medfødte privilegier betød socialt og kulturelt kan man læse om i: Bartholomé og Lucile Bennassar. Bennassar mener således, at den sociale mobilitet var en af årsagerne til, at mange kristne fanger og slaver takkede ja til tilbuddet om at blive "turque de profession «, dvs. om at konvertere til islam. De mener, at udsigten til en mere behagelig tilværelse økonomisk og socialt set var årsag til, at mange kristne endog valgte frivilligt at krydse grænsen til den muslimske verden. 
21 De slaver og krigsfanger, der valgte at konvertere til islam, kom som regel fra de laveste sociale lag i de europxiske samfund. Se herfor: op.cit.

22 Se herfor: op.cit.

23 Se herfor: Ellen G. Friedman: Spanish Captives in North Africa in Early Modern Age, Madison 1983.

24 Cervantes' don Quixote-figur er ofte blev sat i forbindelse med den kritik af den spanske konges imperiale politik og af spaniernes generelle moralske habitus, som blev fremført gentagne gange af forskellige nationaltsindede jurister og økonomisk kyndige fra midten af 1500-tallet og ind i første halvdel af 1600-tallet. I juristen Conzáles de Cellorigo: Memorial de la política necesaria y útil restauración a la república de Espana (1600) om krisen i den spanske økonomi kan man således læse, at opretholdelsen af de privilegier, som hverken købmænd eller handelsmænd kunne få del i, reducerer Spanien: "a une Republica de hombres encantados que viven fuera del orden natural (til en republik bestående af fortryllede mennesker, som lever uden for naturens orden)«. I samme afhandling harcellerer Cellorigo endvidere over, at spanierne som følge af deres nedladende holdning til arbejdet - især til landbrug og handel - investerer guldindtæegterne fra Sydamerika i privat gæld (»censos «) fremfor i produktion af værdier. Og investeringen i »censos « forværrer arbejdsmoralen yderligere, hvad der gør den økonomiske krise endnu dybere, for tilbøjeligheden til at spekulere i gæld betyder, at »el oficial desprecia su oficio, el labrador deja su labranza, el pastor su ganado, el noble vende sus tierras...« (embedsmanden ser ned på sit embede, bonden forlader sin gård, hyrden sine får, og adelsmanden sælger sin jord....). Landet affolkedes, jorden blev ikke dyrket, kvæget ikke passet - for selv almindelige mennesker blev fanget i en psyko-social mimen af adelen. Sammen med andre økonomisk kyndige rådgivere opfordrede Cellorigo Felipe d. 3. til at opgive de imperiale ambitioner i Nordeuropa, Middelhavet og Sydamerika og i stedet føre en merkantilistisk politik, der kunne sætte skub i den nationale produktion. Se: Francisco J. Sanchez: An Early Bourgeois Literature in Golden Age Spain, North Carolina 2003, pp. 32-34.

25 E.D.Marcu: Sixteenth Century Nationalism, pp. 24-25.

26 Cervantes: Don Quixote, København 1998 [1605], bind 1, p. 95.

27 Joseph H. Silverman har i artiklen »On Knowing Other People's Lives, Inquisitorially and Artistically« støvsuget spansk guldalder-litteratur, inklusive Cervantes-forfatterskab, for de mange henvisninger til denne praksis med at skaffe sig viden om folks privatliv og fortid med henblik på at melde dem til inkvisitionen, hvis noget mistænkeligt skulle dukke op.

28 Cervantes' danske oversætter Rigmor Kappel Schmidt har gjort et stort arbejde for at synliggøre de skjulte etniske finter i Don Quixote. Jeg henviser derfor til hendes efterord til den danske oversættelse af Don Quixote, København 1998.

29 La Goleta havde længe været forsømt af Felipe d. 2, der havde nægtet at sende tropper til Tunis for at hjælpe de nødstedte spanske soldater på stedet.

30 På de områder langs den nordafrikanske kyst, som det lykkedes spanierne at erobre fra muslimerne, oprettede man såkaldte presidios - kristne fæestningsværker - der skulle tjene dels som forsvarsværn mod muslimerne dels som udgangspunkt for katolsk missionsvirksomhed.

31 Således hed det i det 16. og det 17. århundrede, når en kristen besluttede sig 
for at konvertere til islam. Se herfor: Bartholomé og Lucille Benassar.

32 For krigsfangen (og Cervantes) synes problemerne med de nordafrikanske presidios i lige så høj grad at være, at disse fæstningsværker gjorde store indhug i statskassen uden at tjene reelle nationale interesser. I virkeligheden er de bare, hævdes det, forfængelige symboler og vidnesbyrd om de spanske kongers imperiale ambitioner.

33 Cervantes: Don Quixote, bind 2, p. 32.

34 Tyrkerne havde truet og angrebet spanierne og spanske skibe i mange år, men her i det første årti af det 17. århundrede var truslen aftaget ikke mindst, fordi spaniernes geopolitiske interessesfære var forrykket fra Middelhavet til Atlanterhavet.

35 På ediktets forside der således: »Den spanske konges edikt om udvisning og fordrivelse af 900.000 moriscos, der planlægger at kaste vores kongerige i favnen på tyrkerne og saracinerne og således overgive spanierne til deres fjendtlige magt«. Eftertiden har ment, at Felipe d. 3. her overdrev antallet af maurere i Spanien. Man taler normalt kun om, at 300.000 maurere blev forvist.

36 Beslutningen om at gennemføre den etniske uddrivelse blev taget samme dag, som Felipe d. 3. var blevet tvunget til at underskrive en våbenhvileaftale i Antwerpen med de uregerlige hollændere, hvad der reelt betød endnu et forsmædeligt militært og politisk nederlag for dette ellers guddommeligt udvalgte folk og endnu en indrømmelse på det udenrigspolitiske område til de protestantiske nordeuropæere.

37 Jvf. Caroll B. Johnson, p. 80.

38 Marcelas mor er død, Zoraidas, Ana Felix’ mor lige så. Ruys svigerinde, broderen Juans kone, mor til datteren Clara, er ligeledes død.

39 Cervantes, bind 1, p. 477.

40 Op.cit., pp. 467-468.

41 Op.cit., p. 14. 